\title{
Nahdlatul Ulama: Bebas untuk Oportunis? Menelisik Kontestasi Politik pada Pemilihan Kepala Daerah Kabupaten Banyumas Periode 2008 dan 2013
}

\author{
Rahmi Hasyfi Febrina ${ }^{1}$ \\ Bangun Udi Mustika ${ }^{2}$ \\ Adek Risma Dedees ${ }^{3}$
}

\begin{abstract}
Nahdlatul Ulama as a religious organization, as independence intermediary organs which is helped the people to represent their interest between public affairs to the state. NU is not seen as opportunistic religion organization and a shamed organization cause of its ideology. More than, NU on politic arena, attempt to return as a religion organization which is has a greatest vission for making importance agenda and welfare of the members of a religion community (umat) life. Unbalancing support of NU at two periods of head of province or district election in Banyumas region on 2008 and 2013 explained that NU stood up to the fortification which likely could guarantee of NU's interest. It does not care about 'inconsistent' stigma which is marked to NU. Thus, welfare and interest of umat are more importance than just having adoration as 'consistence' and 'sportive' religion organization in Banyumas, generally in politic arena. This research is qualitative-interpretative approach. The method is used observation, indeep interview and also utilizing secunder data and documentation matters.
\end{abstract}

\section{Keywords:}

Nahdlatul Ulama; nahdliyin; Pilkada; Banyumas.

\begin{abstract}
Abstrak
Nahdlatul Ulama sebagai organisasi keagamaan, lembaga intermediari yang berdiri sendiri sebagai perpanjang tangan antara masyarakat dan negara dilihat dan dicermati tidak melulu dalam perspektif mereduksi NU kedalam posisi sebagai sang oportunis dan 'tak tahu malu'. Lebih dari itu ialah mencoba mengembalikan NU sebagai organisasi keagamaan yang berorientasi kepada kepentingan dan kemaslahatan umat. Plin plan dukungan politik NU pada dua periode pilkada di Banyumas menjelaskan bahwa NU berpihak kepada kubu yang kira-kira mampu menjamin kemaslahatan umat kelaknya. Tak peduli dengan stigma 'inkonsistensi' yang dilabelkan kepada NU. Kesejahteraan dan kemaslahatan umat Islam di Banyumas jauh lebih penting dan utama dari sekadar dipuja sebagai organisasi 'konsisten' dan 'sportif' dalam kancah politik, jika memilih beroposisi dengan pemerintah. NU tak kenal oposisi, NU hanya konsisten berpegang pada ideologi keagamaan yang mengedepankan kepentingan dan kebutuhan para pengikutnya (umat). Jenis penelitian ini kualitatif-interpretatif. Metode yang dipakai ialah observasi, wawancara mendalam, serta dengan memanfaatkan data-data sekunder atau dokumentasi yang ada.
\end{abstract}

\footnotetext{
1 Mahasiswa Program Magister Ilmu Politik dan Pemerintahan Fisipol UGM

2 Mahasiswa Program Magister Ilmu Politik dan Pemerintahan Fisipol UGM

3 Mahasiswa Program Magister Ilmu Politik dan Pemerintahan Fisipol UGM

Email: adedees@gmail.com
} 


\section{Kata Kunci:}

Nahdlatul Ulama; nahdliyin; Pilkada; Banyumas.

\section{Pendahuluan}

Nahdlatul Ulama (NU) merupakan organisasi kemasyarakatan yang menjadi bagian tak terpisahkan dari sebagian besar bangsa Indonesia. Sebagai organisasi sosial keagamaan, Nahdlatul Ulama hadir di tengah perbedaan-perbedaan pandangan dengan organisasi sosial keagamaan lain. Namun pada dasarnya, NU tetap memegang teguh prinsip persaudaraan (al-ukhuwwah) dan toleransi (al-tasamuh). Hingga sekarang ini NU mampu menjaga kebersamaan dan hidup berdampingan dengan sesama umat Islam maupun dengan sesama warganegara yang mempunyai keyakinan dan agama lain dalam rangka berama-sama mewujudkan cita-cita persatuan dan kesatuan bangsa yang kokoh dan dinamis (AD/ART PCNU Banyumas tahun 2013).

Keberadaan NU yang senantiasa menyatukan diri dengan perjuangan bangsa, menempatkan NU dan segenap warga untuk tetap aktif mengambil bagian dalam pembangunan bangsa menuju masyarakat yang adil dan makmur. Sebagai jami'iyah secara organisatoris tidak terikat dengan organisasi politik dan organisasi kemasyarakatan manapun. Hal ini mendasari bahwa setiap warga NU adalah warga negara yang mempunyai hak-hak politik yang dilindungi oleh undang-undang. Hak politik digunakan secara baik dan bertanggung jawab, sehingga dengan demikian dapat menumbuhkan sikap hidup yang demokratis, konstitusional, taat hukum, dan mampu mengembangkan musyawarah dan mufakat dalam memecahkan permasalahan yang sedang dihadapi bersama. NU merupakan wadah bagi para ulama dan pengikut-pengikutnya yang didirikan pada 16 Rajab 13344H/31 Januari 1926 dengan tujuan untuk memelihara, melestarikan, mengembangkan, dan mengambalikan ajaran Islam yang berhaluan Ahlus Sunnah Wal Jamaah.

Dalam berbagai macam kegiatannya NU melembagakan pola pikir Ahlus Sunnah Wal Jamaah yaitu sebuah paham dan pola pikir yang mengambil jalan tengah antara ekstrim aqli (rasionalis) dengan kaum ekstrim naqli (spirituralis). Karena itu sumber pemikiran bagi NU tidak hanya Al-Qur'an, Sunnah, tetapi juga menggunakan kemampuan analisis akal sehat ditambah dengan realitas empirik. Cara berpikir semacam itu dirujuk dari pemikir terdahulu, seperti Abu Hasan Al-Asy'ari dan Abu Mansur Al-Maturidi dalam bidang teologi. Kemudian dalam bidang fikih mengikuti empat madzhab; Hanafi, Maliki, Syafi'i, dan Hambali. Sementara dalam bidang tasawuf, mengembangkan metode Al-Ghazali dan Junaid Al-Baghdadi, yang mengintegrasikan antara tasawuf dengan syariat.

Gagasan kembali ke khitah pada tahun 1984, merupakan momentum penting untuk menafsirkan kembali ajaran Ahlus Sunnah Wal Jamaah, serta merumuskan kembali metode berpikir, baik dalam bidang fikih maupun sosial. Serta merumuskan kembali hubungan NU dengan negara. Gerakan tersebut berhasil membangkitkan kembali gairah pemikiran dan dinamika sosial dalam NU. NU yang tidak lagi terjun dalam politik praktis namun kini mengabdikan dirinya untuk mendorong tumbuh kembangnya masyarakat mencapai masyarakat yang madani (civil religion), yaitu masyarakat yang berkeadilan dan berperadaban tinggi.

Dalam kancah nasional, NU tidak dipandang semata-mata hanya sebagai organisasi sosial keagamaan, lebih dari itu bahwa NU merupakan satu dari beberapa 
organisasi yang hadir dan turut menentukan konstelasi politik tanah air. Hal ini tidak terlepas dari sejarah panjang dan berliku tentang NU dan ke-Indonesia-an. Entah itu dimaknai sebagai persoalan politik yang beririsan dengan keagamaan, beririsan dengan nasonalisme, beririsan dengan budaya, dan seterusnya yang bersinggungan dengan kepentingan politik. Oleh karenanya, tidak mengherankan jika pada pemilihan legislatif 9 April 2014 kemarin, dan pada pemilihan umum yang sudah-sudah baik dalam skala nasional maupun daerah peran, posisi, dan 'kiblat' NU atas partai politik menjadi perhatian utama (central point) oleh banyak kalangan. Argumen tersebut didasarkan pada NU yang memiliki modal massa yang berlimpah sekaligus solid. Basis nahdliyin ini menjadi semacam 'kartu truf' bagi NU, sebagai penentu terhempas atau lolosnya partai politik dalam arena pemilu.

Sejalan dengan pembangunan dan perkembangan industri dan globalisasi, kehidupan basis pendukung NU mengalami perubahan, baik secara sosio, politik, maupun ekonomi. Nahdliyin yang melakukan urbanisasi tidak sedikit. Pada titik tersebut muncul transformasi atau pembentukan wajah baru NU, mereka yang cenderung dikenal sebagai penduduk desa dan kolot, berubah menjadi lebih modern dan berpendidikan menengah hingga tinggi. Semakin terbukanya sistem pendidikan, basis intelektual NU juga semakin meluas, sejalan dengan cepatnya mobilitas sosial yang terjadi selama ini. NU tidak hanya menjadi kekuatan nasional, namun menjadi mesin politik yang mampu mempengaruhi kebijakan daerah di tingkat provinsi, kabupaten/kota maupun pedesaan. Dalam kontestasi Pilkada, basis massa NU sebagai modal membuatnya tetap menjadi sasaran empuk untuk meraup suara. Modal tersebut merupakan magnet politik yang kuat, untuk menarik perhatian para politisi.

Tak dapat dinafikan bahwa NU masih memiliki kekuatan signifikan. Pada beberapa kali Pilkada di wilayah Banjarnegara, Purbalingga, Banyumas, Cilacap, dan Kebumen (Barlingmascakep) NU menjadi sasaran kantung suara bagi para kandidat. Banyumas misalnya, banyaknya pesantren-pesantren di pedesaan dan sosok kyai yang kharismatik merupakan daya tarik tersendiri bagi warga di sana. Peran kyai tidak semata-mata terkait peran keagamaan dan rohani, namun juga sebagai mitra guna meningkatkan pengaruh elit politik. Peran kyai pun tidak dapat diremehkan dalam persoalan ekonomi, sudah menjadi rahasia umum bahwa rata-rata kyai di Banyumas memiliki tanah yang luas.

Warga Banyumas mayoritas beragama Islam dan merupakan nahdliyin. Meskipun tidak ada identitas yang resmi mengakui dan diakui sebagai nahdliyin, tapi hal itu terlihat pada ikatan semangat kekeluargaan yang kuat. Mereka kokoh memegang prinsip terutama demi mempertahankan ajaran Ahlus Sunnah Wal Jamaah. Warga NU di Banyumas kini bukan hanya yang hidup di desa seperti petani, penderes, dan seterusnya yang kurang memiliki daya tawar politik (political bargaining). Tak sedikit tokoh atau elit NU yang menduduki jabatan strategis dalam lingkup pemerintahan daerah maupun nasional.

Untuk melihat relasi NU dan partai politik bekerja sama dalam percaturan politik di aras lokal, riset ini menjadikan Pilkada Banyumas tahun 2008 dan 2013 sebagai objek kajian. Pada Pilkada 2008, NU saat itu merupakan suatu kekuatan yang mumpuni untuk mendulang suara, terbukti dengan kemenangan MardjokoHusein. Kemenangan pasangan itu disinyalir merupakan prakarsa warga nahdliyin melalui kekuatan Partai Kebangkitan Bangsa (PKB). Asumsinya, jika dilihat dari kekuatan PKB maka suara yang dimiliki belum terlalu signifikan untuk memenangkan Pilkada, namun sebagian masyarakat awam menganggap PKB sebagai kendaraan politik NU. Meski belum ada klaim resmi yang mendukung asumsi itu, kenyataannya banyak tokoh PKB adalah warga nahdliyin. 
Di samping itu, terdapat fenomena kontradiktif terjadi pada Pilkada 2013. Husein yang sebelumnnya adalah wakil bupati kemudian mencalonkan diri sebagai bupati. Saat itu dirinya diusung oleh Partai Demokrasi Indonesia Perjuangan (PDIP) dan sukses melenggang ke kursi Bupati Banyumas. Kesuksesannya bukan semata-mata hasil dari kerja mesin politik partai tetapi berkat berhasil dipegangnya simpul NU, yaitu Ketua PCNU Kabupaten Banyumas. Dapat diasumsikan bahwa basis massa NU pun beralih dan telah dikuasai. Hal itu merupakan jalan mulus bagi kemenangan Husein dan pasangannya, Budi. Di tengah menurunnya kepercayaan masyararakat terhadap partai politik, NU sebagai organisasi alternatif hadir untuk memberikan ruang partisipasi dan harapan bagi masyarakat, juga menjadi semacam panduan politik dalam mencoblos calon pemimpin dalam Pilkada.

Di tengah posisi dan peran NU yang vital dan strategis ini, afiliasinya ke beberapa partai politik menarik dicermati ulang. Apabila melihat pertarungan politik kontemporer saat ini, kekuatan dan kekuasaan NU terhadap partai politik tidak bisa dilihat sebelah mata, terlebih secara historis NU adalah organisasi massa yang beririsan dengan partai politik. Ada kekuatan yang bisa dipetakan secara kasat mata, misal massa NU yang banyak dan tersebar di belahan sudut Indonesia, serta kekuasaan imajiner, yang cukup licin dibaca karena berjalin berkelindan dengan kepentingan dan praktik politik.

Perjalanan sejarah NU hampir selalu bersentuhan dengan politik, kekuasaan, negara, dan kebijakan publik, baik sebagai pelaku utama, pendukung, maupun sekadar pengikut. Bentuk organisasinya berubah-ubah secara dinamis, mengikuti perkembangan politik pada masanya. Mulai dari organisasi sosial keagamaan, menjadi organisasi politik, kembali menjadi organisasi sosial keagamaan, kemudian berubah lagi menjadi organisasi sosial keagamaan yang mendirikan partai politik.

Bila mencermati beberapa pemilihan kepala daerah dan pemilihan calon anggota legislatif baru-baru ini, kekuatan serta kekuasaan NU menjadi makin menarik untuk dipetakan. Kaitannya tak hanya tentang memahami NU dari sudut pandang baru dan perspektif kekinian, melalui cara terbaik. Dalam konteks ini, perkembangan politik demokratis tidak bisa dipisahkan dari pesantren. Selain menjadi lembaga pendidikan yang merupakan basis gerakan NU, pesantren juga merupakan entitas politik.

Persaingan para elit NU dalam memperebutkan kekuasaan, baik pusat ataupun daerah, menunjukkan bahwa NU telah jauh masuk ke dalam pusaran liberalisasi politik. Elit yang memilih terjun dalam politik pragmatis ini membuat mereka terfragmentasi di partai politik. Perebutan akses politik kini jelas sarat akan kepentingan ekonomi pribadi ataupun golongan. Figur kyai yang biasanya disegani masyarakat NU juga masuk dalam pusaran politik pragmatis, terutama di daerah basis suara NU. Implikasinya adalah delegitimasi peran kyai sebagai culture broker atau agent of change. Dengan demikian, seperti yang telah dipaparkan sebelumnya, riset ini mencoba memetakan dan melihat relasi NU dan partai politik dalam pesta demokrasi di aras lokal.

\section{Pemilihan Kepala Daerah Kabupaten Banyumas Periode 2008}

Pasangan Mardjoko dan Husein memenangkan Pilkada 2008 yang diusung oleh PKB. Mardjoko adalah warga atau anggota Muhammadiyah, kelompok minoritas di Banyumas, karena hampir $78 \%$ penduduk Banyumas adalah nahdliyin. ${ }^{4}$ Sementara Husein menjabat sebagai Kepala Dinas PDAM dan relatif netral, bukan warga NU maupun

\footnotetext{
4 Wawancara dengan Ketua PCNU Maulana Ahmad Hasan, 15 Juni 2014 di Banyumas
} 
Muhammadiyah. Mardjoko sebagai kader PKB memiliki kemampuan negosiasi yang baik dan menyakinkan. Saat Pilkada ia mendekati Ketua PCNU, Taifur Arafat, sebagai camat di salah satu kecamatan Banyumas. Taifur dan Mardjoko adalah teman lama dan akrab, kemenangannya pada Pilkada tak lepas dari bantuan Taifur. Ketika Mardjoko-Husein menjabat, Taifur pun menduduki posisi Kepala Pusdiklat Banyumas, beberapa elit NU pun menempati posisi strategis dalam birokrasi pemerintah daerah.

Meski beberapa elit NU menduduki posisi penting, kebijakan tidak otomatis berpihak pada kepentingan warga NU. Alokasi bantuan dana pada pesantren, pendidikan, pengajian, dan lainlain masih tetap minim. Gaya kepemimpinan Mardjoko tidak membiarkan elit ini leluasa mengendalikan dan membuat keputusan dalam kebijakan tertentu. Entah melalui tangan elit NU ataup tidak, Mardjoko tidak segansegan memecat birokrat di bawahnya yang berseberangan ide dan gagasan, meskipun itu dari kalangan NU.

Persoalan lainnya, kebijakan publik yang dibuat Mardjoko cenderung mengabaikan kepentingan warga NU, terutama level akar rumput (grassroots) di desa dan kampung, yang tadinya adalah basis massa yang memenangkan bupati ini. Seiring dengan semangat pembangunan dan industrialisasi, pada era Mardjoko beberapa investor diundang untuk turut serta membangun dan membuka lapangan kerja di Banyumas. Ironisnya, kebijakan ini tidak mendatangkan manfaat bagi warga NU. Mardjoko kurang melibatkan warga NU dalam proses pembentukan dan pengembangan Banyumas, agar menjadi kota baru menuju metropolitan.

Ia lebih memprioritaskan pembangunan fisik kota, demi menarik dan memberi kenyamanan calon investor yang akan berinvestasi, ketimbang hal-hal yang berkaitan dengan sarana pendidikan masyarakat dan aspek kultural di sana. Sikap ini melahirkan kekecewaan warga NU terhadap Mardjoko. Kesan yang kemudian terbangun dan berkembang adalah Mardjoko berkhianat atas segala kebaikan dan kepercayaan warga NU, yang pernah diamanahkan kepadanya.

\section{Pemilihan Kepala Daerah Kabupaten Banyumas Periode 2013}

Pada Pilkada 2013, Mardjoko dan Husein kembali berlaga. Hanya saja, kali ini mereka menjadi rival. Mardjoko berpasangan dengan aktor lain, begitu juga Husein. Jika tahun 2008 mereka bersatu dan diusung oleh partai yang sama yaitu PKB, tahun 2013 pasangan Mardjoko diusung oleh Partai Golkar, dan pasangan Husein diusung PDIP. Singkat cerita, laga politik dimenangkan oleh pasangan Husein yang diusung PDIP. Menariknya, perlu dicermati bahwa Husein bukanlah dari kalangan nahdliyin.

Jika ditelisik ke belakang, ternyata ditemukan ada beberapa deal politik antara Husein dengan NU. Kesepakatan politik ini tidak melulu dalam bentuk penempatan elit NU pada posisi strategis di birokrasi pemerintah, seperti yang terjadi pada era Mardjoko, lebih dari itu, yaitu keberpihakan Husein kepada program-program NU yang diusung nahdliyin. Baik berwujud alokasi anggaran pendidikan, kegiatan sosial keagamaan, kegiatan kelompok muda nadliyin, dan seterusnya.

Untuk mewujudkan hal ini, elit NU di Banyumas seperti Ketua Dewan Pembina NU yaitu Kyai Sobri dan Ketua PCNU yaitu Gus Hasan, menyadari betul posisi NU sebagai organisasi keagamaan yang diharapkan tidak kaku dan antipolitik. NU memang dikehendaki terlibat dan campur tangan pada proses pembentukan kebijakan pemerintah di Banyumas. Bahkan di rezim Husein ini, NU membangun Tim Pemenangan Politik yang dikenal dengan Tim Siasyah, yang agaknya merupakan kontrak politik Husein dan NU. Pembentukan ini sebagai bentuk keseriusan dan niat kuat NU untuk terlibat dan turut 
menentukan peta pertarungan politik di Banyumas.

Di balik kotrak politik itu, meski relatif menguntungkan NU, tidak bisa disebut sebagai era emas pemerintahan Banyumas. Di balik ketentraman dan stabilitas yang dibangun, baik secara politik, sosial, dan agama, Husein tidak membuat terobosan yang berarti. Era pemerintahan ini hanya membuat roda kehidupan Banyumas berputar konstan dan berulang begitu saja. Nyaris tak ada inovasi yang signifikan atau buah kerja yang khas.

Proses pembangunan yang terjadi saat ini adalah lanjutan dari pemerintahan Mardjoko, dengan kesepakatan ekonomi dan politik yang sudah diselesaikan pada masanya. Pada titik ini dominasi NU terasa kental. Berembus kabar, ada pendanaan berjumlah besar dari Husein kepada NU, namun tidak terekspos ke publik. Besar kemungkinan kondisi ini semacam 'bayar hutang' Husein kepada NU, yang sudah berjasa mengusungnya.

Terlepas dari stigma dikotomi baikburuk yang melekat pada peran dan relasi NU dengan partai politik dan pemerintah daerah Banyumas, dua Pilkada ini memperlihatkan bahwa NU berperan besar dalam pemenangan pemilu serta pembuatan kebijakan daerah. Elit dan akar rumput NU saling menopang kepentingan dalam proses pemilihan kepala daerah. Kekalahan Mardjoko pada Pilkada 2013 adalah bentuk resistensi warga NU yang merasa dikecewakan. Sedangkan kemenangan Husein sama sekali tidak terkait mitos bahwa NU setia dengan PKB, atau PKB adalah NU.

Mitos bahwa apapun partai yang menjadi kendaraan, selagi kepentingan NU turut dibawa maka organisasi ini akan setia menemani dan membantu, sudah terpatahkan. Hal ini juga berkaitan dengan tren kemenangan PDIP yang menjadikan Jawa Tengah sebagai kantong suara terbesarnya. Tak bisa pula diabaikan ekspansi para kader NU membentuk sayap Islamis ke beberapa partai politik nasionalis. Ditambah lagi, sosok Joko Widodo yang tengah naik daun dan PDIP yang turut kecipratan kepopuleran Jokowi.

Pada titik akhir, Pilkada Banyumas adalah kontestasi NU dengan aktor demokrasi. Penelitian ini akan memfokuskan kajian pada bagaimana relasi antara NU dan partai politik terbangun pada Pemilihan Kepala Daerah di Banyumas (2008 dan 2013)? Bagaimana NU menempatkan ideologi mereka di tengah stigma sebagai organisasi pragmatis, transaksional, dan oportunistik?

\section{Kajian Pustaka}

Ada beberapa kajian literatur tentang NU dan relasinya dengan partai politik yang coba diidentifikasi dan isu-isu yang dipetakan. Hafis Muaddab dalam Peran Nahdlatul Ulama sebagai Opinion Leader dalam Membangun Politik Demokrasi di Indonesia (2012) menjelaskan bahwa peran politik NU sebagai opinion leader, dibangun dalam tiga fungsi yaitu fungsi kultur sosial, advokasi dan literasi politik, serta fungsi jejaring sosial. Fungsi-fungsi tersebut adalah suatu rangkaian saling terkait. Bekerjanya salah satu fungsi perlu didukung oleh fungsi lain, sehingga peran politik terbentuk nyata dan maksimal.

Dalam konteks politik dan masyarakat kontemporer saat ini, pelaksanaan peran politik NU diharapkan tidak meninggalkan fungsi sosialnya sebagai ormas keagamaan di Indonesia. Meninggalkan fungsi ini berarti tidak hanya mengingkari khitah 1926 tetapi juga membuat rapuhnya bangunan peran politik NU itu sendiri. Dengan demikian, fungsi sosial NU merupakan landasan keorganisasian NU sebagai ormas keagamaan, sedangkan perannya dalam politik lebih sebagai upaya melindungi tatanan sosial kemasyarakatan, yang dibangun berdasarkan nilai-nilai Islam Ahlus Sunnah Wal Jamaah.

Selanjutnya, Saipul Hamdi dalam Politik Islah: Re-Negosiasi Islah, Konflik, dan Kekuasaan dalam Nahdlatul Wathan di Lombok Timur (2011), menjelaskan bahwa islah atau rekonsiliasi dapat 
tercapai di kalangan elit Nahdlatul Wathan (NW) yang tengah berkonflik pasca wafatnya tokoh kharismatik, Maulana Syaikh di Pancor, Lombok pada 1997. Konflik pun berlanjut ke hal yang sarat muatan politik, ekonomi, dan kekuasaan antara dua kubu. Kubu tersebut masing-masing dipimpin oleh keluarga putrinya yaitu kubu Rauhun (R1) dan kubu Raihanun (R2).

NW adalah organisasi sosial keagamaan yang didirikan pada 1953 oleh Tuan Guru Haji Muhammad Zainuddin Abdul Madjid atau Maulana Syaikh yang menganut aqidah Ahlus Sunnah Wal Jamaah. Sejak berdiri, NW telah aktif pada kegiatan politik praktis karena Maulana Syaikh sendiri adalah penasihat Partai Masyumi pada 1952. Pada pemilu 1999 kubu R1 bergabung dengan PBR dan kubu R2 memilih tetap dengan Partai Golkar. Pada pemilu 2004 kubu R1 bergabung dengan PBB dan kubu R2 bergabung dengan PBR. Tahun 2009 kubu R1 bergabung dengan Partai Demokrat dan kubu R2 merapat ke Partai Gerindra.

Penelitian ini menjelaskan bahwa ranah politik menjadi media islah, karena ranah yang lain tidak dapat diterima dan tidak marketable bagi kedua kubu. Langkah islah dengan jalan politik mengindikasikan bahwa faktor kekuasaan sangat dominan diantara elit NW, selain faktor ekonomi dan keluarga. Ketika faktor kekuasaan yang lebih dominan, maka jalan islah yang harus ditempuh adalah jalur politik atau sharing kekuasaan.

Selanjutnya kajian tentang Islam dan politik juga ditulis oleh Abdul Gaffar Karim dalam Islam di Panggung Politik Indonesia: Latar Belakang, Dinamika, dan Pergeserannya (1997). Karim menjelaskan bahwa agama (Islam) sejauh ini telah mapan sebagai salah satu variabel penting yang turut menentukan warna sebuah pentas politik. Bahkan penggunaan bendera agama di atas panggung politik hingga saat ini telah sangat lazim. Artinya, kekuatan politik yang berpijak pada nilai dasar keagamaan adalah sesuatu yang tak terhindarkan. Apalagi jika agama itu menjadi anutan mayoritas, seperti Islam di Indonesia. Kekuatan politik dengan ciri demikian harus selalu disertakan dalam wacana keilmuan yang sedang berlangsung.

Dalam konteks Indonesia kemestian ini kental, jika mengingat Islam yang merupakan agama mayoritas bukan saja tak pemah absen tampil dalam nuansa politik, tapi juga karena beberapa karakter khas berikut ini. Pertama, terbangunnya suatu mitos tentang retak antara Islam dan negara. Mitos yang telah ada paling tidak, sejak masa Mataram. Kedua, adanya standar ganda penguasa terhadap Islam, yang menjadikan perilaku penguasa itu berbeda, yaitu ketika lslam dipahami sebagai realitas sosial dan ketika dipahami sebagai kekuatan politik. Sebagai realitas sosial, Islam adalah sebuah sumber legitimasi penting yang tak bisa dipandang sebelah mata. Namun sebagai sebuah potensi kekuatan politik, Islam adalah salah satu sasaran penataan represif utama.

Ketiga, adanya perdebatan visi yang tak pernah usai di kalangan umat Islam lndonesia, tentang wujud dan cara pencapaian aktualisasi lslam dalam kehidupan berbangsa dan bernegara. Sebuah perdebatan yang sampai tingkat tertentu bisa dipahami sebagai refleksi silang pemikiran di kalangan cendekia Islam, di seluruh dunia pada umumnya. Perdebatan visi ini sekaligus melahirkan keragaman orientasi gerakan di kalangan umat, sekaligus diikuti fenomena kelahiran 'santri baru' dengan pandangan akan Islam dan politik yang berbeda, kritis, dan bisa saja lebih progresif.

Kajian tentang NU juga diulas oleh Mohamad Sobary dalam NU dan Keindonesiaan (2010). Kumpulan tulisan dari berbagai pemikir dalam dan luar NU ini, lebih seperti harapan warga NU terhadap peran NU yang ideal. Terutama ketika berhadapan dengan berbagai konfigurasi konteks sosial, politik, maupun ekonomi dan tuntutan pluralitas yang semakin tinggi, berubah, dan sulit diprediksi dewasa ini. NU sadar betul akan proses perubahan sosial yang sangat besar ini, yaitu metamorfosis 
politik yang bergerak dari lingkungan umat nahdliyin ke lingkungan warga negara.

Sikap warga negara yang concerned dan committed memang diperlukan untuk mengambil langkah-langkah penyelamatan atas berbagai ancaman. NU ingin menunjukkan bahwa dalam situasi tersebut, tanpa keributan, haus sanjungan, NU tetap bisa menjadi pelopor untuk muncul ke permukaan menampilkan performanya, bersama segenap unsur civil society. Hal ini dilakukan demi bertanggung jawab terhadap bangsa dan negara meskipun NU dan Muhammadiyah tak dihargai sama sekali oleh pemerintah. Pemerintah lebih memilih sibuk bekerja sama dengan para politikus, yang orientasi pengabdian kebangsaannya perlu dikritisi ulang.

Dari beberapa literatur di atas, kajian mengenai NU sebagai organisasi Islam cukup variatif dan dihadirkan dalam perspektif yang berbeda. Beberapa kajian, umumnya mengidentikkan NU sebagai organisasi keagamaan yang dihubungkan dengan konteks kehidupan sosial, ekonomi, hingga arena politik dalam pentas demokrasi. Namun sejauh itu, pandangan formalistik mengenai NU sebagai organisasi keagamaan yang normal, independen, dan berjalan sesuai khitahnya perlu untuk kita kesampingkan.

Fakta bahwa kekuasaan menjadi kontestasi dan Pilkada adalah arena bergengsi di balik lazimnya partai polik sebagai pilar demokrasi, NU justru hadir di dalamnya. Bermanuver dengan indah di luar persoalan 'bunglon' apalagi opotunistik. Tulisan ini akan menyorot NU dalam kacamata lain, terlepas dari pandangan NU secara umum sesuai dengan pakem keorganisasian. Klaim PKB atau PPP sebagai afiliasi dari kelompok nahdliyin terbukti gagal, NU ternyata bisa sekawan sesahabat dengan partai politik nasionalis atau 'sedikit' sosialis macam PDIP. NU mampu berjalan sendiri membuka lebar peluang politik dalam relasi dan kontestasi kekuasaan di ranah lokal, di luar dari teori besar yang menjelaskan bahwa NU sudah dipastikan akan setia pada PKB atau PPP, yang sama-sama mengusung ideologi keagamaan, yaitu Islam.

\section{Habitus, Arena, dan Kapital: Bangunan Utama Orientasi Politik Nahdlatul Ulama}

Kemenangan dua kepala daerah pada Pilkada di Banyumas tahun 2008 dan 2013 sama-sama menempatkan NU sebagai basis kekuatan utama. NU dipilih karena posisinya sebagai 'mesin' penyedia suara terbesar dan kecenderungan politiknya yang anti 'beroposisi' dengan pemerintahan status quo. Untuk menjelaskan semua itu, penelitian ini memakai teori strukturasi Pierre Bourdieu sebagai pisau analisis. Tiga konsep utama yang dipakai dalam menganalisis kasus ini yaitu, habitus, kapital, dan arena.

Bagi Bourdieu, membahas habitus secara memadai bagai mengandaikan suatu bentuk epistemologi sejarah dalam arti mengungkap relevansi praktis suatu wacana. Sebagai sebuah sejarah, habitus menghasilkan praktik-praktik, baik individual maupun kolektif, sesuai skema yang dikandung oleh sejarah. Habitus menjamin kehadiran aktif pengalaman-pengalaman masa lalu yang diletakkan dalam setiap organisme dalam bentuk skema persepsi, pemikiran dan tindakan, terlebih semua aturan formal dan norma tersurat, untuk menjamin kesesuaian praktik-praktik sepanjang waktu (1979, viii).

Habitus menjamin koherensi hubungan konsepsi masyarakat dan pelaku. Ia menjadi perantara antara individu dan kolektivitas. Habitus memungkinkan dibangunnya teori produksi sosial pelaku dan logika tindakan. Ia merupakan faktor penjelasan logika berfungsinya masyarakat. Keseragaman habitus dalam suatu kelompok menjadi dasar perbedaan gaya hidup dalam suatu masyarakat. Dalam perspektif ini, sosialisasi menjadi bentuk pengintegrasian habitus kelas. Ia menghasilkan kepemilikan individu pada 
kelas dengan mereproduksi kelas sebagai kelompok yang memiliki kesamaan habitus.

Maka konsep ini menjadi titik-tolak reproduksi tatanan sosial. Setiap sistem disposisi individu adalah variabel struktural sistem disposisi yang lain, terungkap kekhasan posisinya di dalam kelas dan arah yang dituju. Gaya pribadi, praktik-praktik kehidupan atau hasil karya, tidak lain kecuali suatu jarak terhadap gaya khas suatu jaman atau kelas, sehingga gaya itu mengacu pada gaya umum, tidak hanya melalui keseragaman, tetapi juga melalui perbedaan yang menghasilkan pembawaan tertentu.

Bagi Bourdieu habitus adalah jenis sistem disposisi, yaitu kondisi yang terkait dengan syarat-syarat keberadaan suatu kelas akan menghasilkan suatu habitus: sistemsistem disposisi yang tahan waktu dan dapat diwariskan, struktur-struktur yang dibentuk dimaksudkan agar berfungsi sebagai strukturstruktur yang membentuk. Artinya, sebagai prinsip penggerak dan pengatur praktik-praktik hidup yang representasi-representasi, yang dapat disesuaikan dengan tujuan-tujuan, tanpa mengandaikan pengarahan tujuan secara sadar dan penguasaan secara sengaja atas upaya-upaya yang diperlukan untuk mencapainya. Hal itu secara objektif diatur dan teratur tanpa harus menjadi buah dari kepatuhan akan aturanaturan, dan secara kolektif diselaraskan tanpa harus menjadi hasil dari pengaturan seorang dirigen (Bourdieu, 1980: 80).

“.. Bourdieu interests in using habitus was in understanding what we call the 'individual' is shaped by social structure. By that, he referred to the internalisation of social structure, which then serves to act as a generative system within the individual. By using habitus as structuring mechanism, Bourdieu analysis the relationship between individual practice (permanent dispositions) and the world in general, thus bridging the gap between structuralism and phenomenology," (Mahar and Wilkes dalam Simons, 2006: 221-222).
Sedangkankonsepsi arenayang digunakan Bourdieu, hendaknya tidak dipandang sebagai arena yang berpagar di sekelilingnya atau dalam pengertian domain Amerika, melainkan lebih sebagai 'arena kekuatan'. Hal ini karena adanya tuntutan untuk melihat arena tersebut sebagai dinamis, suatu arena tempat beragam potensi eksis. Konsepsi ini diperbandingkan dengan 'bingkai', 'aturanaturan ketidakrelevanan (rules of irrelevances)'. Karenanya, arena merupakan arena kekuatan yang secara parsial bersifat otonom dan juga merupakan suatu arena yang di dalamnya berlangsung perjuangan posisi-posisi.

Perjuangan ini dipandang mentransformasi atau mempertahankan arena kekuatan. Posisi-posisi ditentukan oleh pembagian modal khusus untuk para aktor yang berlokasi di dalam arena tersebut. Ketika posisi-posisi dicapai, mereka dapat berinteraksi dengan habitus, untuk menghasilkan posturpostur (sikap-badan, 'prises de position') berbeda yang memiliki suatu efek sendiri pada ekonomi 'pengambilan posisi' di dalam arena tersebut (Bourdieu, 1983: 312).

"... society was a system of fields which
are autonomous but which exist in
relationship to one another, and which
collectively exist within a larger social
space (defined as the overall conception of
the social world). Each field has its own
structure and field of forces organized
around specific capitals, which are used
in competitive and strategic ways. Fields
are dynamic, as Wacquant says; fields
are not dead structure or sets of 'empty
places' but a space of play," (Mahar and
Wilkes dalam Simons, 2006: 222).

Dalam semua masyarakat, selalu ada yang menguasai dan dikuasai. Hubungan dominasi ini tergantung pada situasi, sumber daya (kapital) dan strategi pelaku. Pemetaan hubungan kekuasaan didasarkan atas kepemilikan dan komposisi kapital tersebut. Bourdieu membagi 
kapital menjadi empat macam, yaitu kapital budaya, sosial, simbolik, dan ekonomi. Kapital budaya yaitu segala suatu bentuk kekayaan simbolis yang mengacu pada pengetahuan, yang diperoleh lalu menjadi disposisi. Misalnya ijazah, pengetahuan, kode budaya, cara berbicara, kemampuan menulis, cara pembawaan, dan cara bergaul yang berperan dalam penentuan kedudukan sosial.

Kapital sosial yaitu segala sesuatu yang berhubungan dengan jaringan dan koneksi, sebagai sumber daya untuk penentuan kedudukan sosial. Kapital simbolik yaitu segala sesuatu yang berkaitan dengan kekuasaan simbolik seperti jabatan, mobil mewah, kantor prestise, gelar, status tinggi, nama keluarga, dan semua bentuk pengakuan oleh kelompok, baik secara institusional atau tidak. Kapital ekonomi yaitu segala sesuatu yang berkaitan dengan sarana produksi dan finansial, sebagai kapital yang paling mudah dikonversikan ke kapital-kapital lainnya (Boudieu, 1977: 178; Mahar and Wilkes dalam Simons, 2006: 224).

NU sebagai organisasi kemasyarakatan berbasis agama terbesar di Banyumas tidak bisa dilepaskan dari tradisi pesantren, santri, dan kyai dalam praktik berpolitik mereka. Pesantren dan tempat mengaji yang tersebar di sudut-sudut Banyumas merupakan tempat habitus bekerja. Melalui pesantren ini kepribadian diri, etos kerja, nilai-nilai sosial dan agama yang dianut adalah hasil dari bentukan dan disebarluaskan ke dalam dan ke luar pesantren.

Habitus dibangun dari tiga aspek yaitu proses perolehan, dasar kepribadian, dan logika sosial (Boudieu, 2002: 24). Tiga aspek ini membentuk bagaimana para santri dan calon kyai atau ustad-ustadzah dari para pesantren itu dibentuk. Misalnya, pandangan politik para kyai yang disebarluaskan di dalam pesantren secara terus menerus, dengan berbagai argumen dasar ilmiah, maupun sesuai dengan paradigma agama akan menjadi semacam 'fatwa' wajib di lingkungan pesantren tersebut. Fatwa ini kemudian menjadi dasar kepribadian para santri yang sudah terlebih dahulu mengidolakan atau mengagumi sang kyai, entah itu sifatnya, cara berbicara, pembawaan diri, kepatuhan, dan seterusnya.

Dasar kepribadian ini kemudian dijadikan dasar dari logika berpikir para santri ketika keluar dari pesantren. Logika ini juga menjadi logika sosial ketika para santri terjun ke masyarakat. Dengan bahasa lain, teladan yang diperoleh dari pesantren merupakan bentuk habitus bekerja.

Pedoman ajaran keagamaan bagi umat nahdliyin di Banyumas erat kaitanya dengan prefensi politik yang ada. Habitus diistilahkan sebagai kesadaran praktis (practical consciousness), Menurut Bourdieu, habitus, modal, dan ranah berkaitan erat satu sama lain. Saling keterkaitan keduanya akan membentuk praktik. Sebuah hasil penelitian yang ditulis oleh Lutfi Makhasin menekankan satu hal yang sangat pokok dalam doktrin sufi, yang mengajarkan pada pengikutnya bahwa Tuhan bisa digapai dengan praktik pemurnian hati dan penyucian diri secara terus-menerus, dengan cara dzikir dan perantaraan guru (mursyid).

Dalam tarekat, orang dihargai tinggi karena kemampuannya untukberlaku konsisten antara hati, laku ucapan, dan tindakan. Internalisasi pandangan ini sedikit banyak turut andil dalam membentuk habitus politik, yang tidak hanya berdasarkan kemampuan melakukan penilaian rasional, tapi juga pada penilaian konsistensi antara laku ucapan dan tindakan yang dilakukan orang lain, terutama pemimpin. Seperti pada ungkapan Jawa jarkoni, yaitu ngajar ora nglakoni (mengajari tapi tidak melakukan atau memberi contoh), bisa menjadi ilustrasi untuk menjelaskan internalisasi nilai sufistik ini dalam hubungan sosial orang Banyumas. Penghargaan dan juga loyalititas kepada pemimpin bagi masyarakat Banyumas sangat ditentukan oleh kemampuan si pemimpin untuk tidak bertindak jarkoni (Makhasin, 2007: 4). 
Nilai spiritual menjadi modal sosial yang tidak terpisahkan dari kesadaran praktis untuk memilih sebuah pemimpin. Pilkada 2008 dan 2013 ketika kandidat menggandeng NU sebagai representasi umat muslim Banyumas adalah bukti munculnya hubungan nyata dari modal spritual menuju sebuah tindakan atau praktik politik yang ada. Tidak dapat dipungkiri bahwa seiring perkembangan zaman dengan munculnya modernisasi Islam, belum mampu untuk mengikis kekuatan sufisme di Banyumas, buktinya mayoritas muslim Banyumas masih didominasi golongan nahdliyin.

NU di Banyumas tak hanya kuat secara agama, namun juga ekonomi. Setiap desa atau kampung kaum nahdliyin memiliki koperasi simpan pinjam yang dikelola secara mandiri oleh warga setempat. Belum lagi, mereka juga membangun paguyuban-paguyuban yang bergerak di bidang pertanian dan perkebunan. Kemandirian pengelolaan ini bisa dibaca sebagai modal yang dimiliki NU pada setiap desa yang mereka tempati. NU tidak melulu terikat dengan sistem dagang yang dikendalikan oleh pasar secara umum.

Kekuatan ekonomi dan massa yang loyal ini membuat mereka mampu menciptakan pasar sendiri, entah itu dipergunakan untuk kemaslahatan warga NU maupun juga terbuka bagi kalangan umum. Modal ekonomi inilah yang dimiliki NU di Banyumas. Dengan modal ini, kemandirian itu dibangun sekaligus menjadi daya tawar bagi NU terhadap pihak luar yang akan mencoba 'merayu' NU, entah itu dalam kepentingan politik maupun lainnya.

Kedudukan NU di Banyumas tidak bisa dilepaskan dari peran dan posisiNU secara umum di Indonesia. Sejarah organisasi keagamaan ini juga tidak bisa dilepaskan dari sejarah politik bangsa ini. Kebesaran NU sebagai organisasi keagamaan berjalan beriringan dengan kebesaran para pendiri, pemimpin, kyai, alim ulama yang membesarkan NU, pun sebaliknya, NU turut serta membesarkan para ulama tersebut. Sebut saja, Gus Dur, Gus Mus, dan banyak lainnya.
Di Banyumas, kebesaran NU tidak terlepas dari peran kyai beserta anak menantu dan turunannya dalam menentukan peta politik. Kyai Sobri dan Gus Hasan, misalnya, merupakan aktor-aktor di tubuh NU yang berpengaruh terhadap pemenangan Pilkada di sana pada 2008 dan 2013. Kekuataan NU juga terlihat dari sisi keorganisasian yang cukup kuat, mengakar sampai level grassroot. Struktur organisasi NU dari mulai lembaga, lajnah dan badan otonom memiliki tugas dan fungsi yang mencakup seluruh aspek kebutuhan dan kehidupan, menyangkut kesejahteraan warga nahdliyin. Organisasi yang kuat dari hulu, cabang, hingga ranting yang mengakar menjadi bagian dari modal utama dalam kontestasi politik.

Di sinilah kemudian modal sebagai kekuatan itu bekerja. Jaringan NU yang kuat dan masif, didukung oleh kyai sebagai aktor besar, adalah modal utama untuk mengkonstruksi pengaruh, untuk tidak mengatakan dominasi kyai terhadap nahdliyin. Pengaruh itu berproses dan mengakar kuat, mulai dari pesantren hingga ke sumsum struktur sosial terkecil di Banyumas, yakni keluarga. Kyai-kyai NU mempunyai modal budaya yang kuat entah dalam bentuk penghadiran yang kharismatik, personal, yang kemudian menjadi 'mitos' dan standar bagi nahdliyin untuk bertindak.

Ia menjadi simbolisasi yang sakral, diperkuat pula oleh budaya yang mendarah daging bahwa tak ada alasan untuk 'berpaling' dari kyai. Tidak berlebihan jika ada ungkapan kyai adalah 'wakil' Allah SWT sepeninggal nabi. Inilah yang disebut oleh Bourdieu sebagai tindakan bermakna itu. Tindakan nahdliyin diarahkan pada makna tindakan terkait reaksi orang lain atau perilaku orang lain, yaitu kyai sebagai suri tauladan. Oleh karenanya, aspek simbol dalam hal ini adalah proses mitos terhadap kyai dilakukan secara besar-besaran, yang justru terjadi dua arah: kyai terhadap santri dan santri terhadap kyai.

Partai politik dan aktor demokrasi yang berkepentingan tidak bisa menafikan peran 
mereka sebagai kunci yang harus dipegang atau bahkan 'dijinakkan' jika ingin menang bertarung di Banyumas. NU dengan para tokohnya memperlihatkan bahwa NU memiliki modal jaringan atau koneksi, yang tak bisa dinilai sebelah mata. Modal sosial ini tak bisa diraba namun dapat dirasakan ketika pertarungan terjadi, strategi pemenangan pun tak bisa dilepaskan dari pengelolaan modal ini.

\section{Nahdlatul Ulama dan Politik: Pilkada sebagai Arena}

Pemilihan kepala daerah di Banyumas merupakan arena pertarungan yang luar biasa bagi NU dan partai politik yang berkepentingan di dalamnya. NU sebagai organisasi keagamaan terbesar dan paling berpengaruh dalam pemenangan aktor demokrasi beserta partai politik yang bertarung, tak bisa diabaikan begitu saja. Pilkada menjadi arena permainan bagi NU, aktor demokrasi, dan tentunya partai politik. Tiga pemain ini masing-masing mengunggulkan apa-apa yang mereka miliki. Menonjolkan kelebihan guna menarik simpati dan empati calon pemilih adalah strategi yang tidak berdiri sendiri. Ia berjalin dengan banyak aspek entah kultural, sosial, maupun politik dan ekonomi.

Pilkada sebagai arena, tidak berada dalam kondisi statis, melainkan dinamis. Pilkada menyuguhkan beragam aktor yang saling berebut pengaruh dan kepentingan, guna mencapai tujuan dalam kompetisi atau pertarungan, yakni kemenangan. NU yang mau tak mau terlibat dalam pusaran arena, turut serta menentukan posisi dan melakukan daya tawar sesuai dengan orientasi yang akan diinginkan. NU sebagai organisasi keagamaan yang dikaji dalam penelitian ini, mulai memainkan modal-modal atau sumber daya yang dimiliki untuk memberi atau mencabut pengaruh kepada aktor demokrasi, berserta partai politik yang tengah bertarung.

Pasangan Mardjoko dan Husein memenangkan Pilkada 2008 di Banyumas yang diusung oleh Partai Kebangkitan Bangsa (PKB). Mardjoko adalah warga Muhammadiyah yang merupakan kelompok minoritas di Banyumas. Sementara Husein menempati posisi sebagai Kepala Dinas PDAM dan bukan warga NU maupun Muhammadiyah. Mardjoko sebagai kader PKB memiliki kemampuan bernegosiasi yang bagus dan menyakinkan. Pada Pilkada 2008 itu ia mendekati Ketua PCNU Taifur Arafat, yang juga menduduki posisi sentral di pemerintahan sebagai kepala Pusdilkat Banyumas. Atas bantuan Taifur, Mardjoko berpasangan dengan Husein memenangkan Pilkada 2008 di Banyumas.

Transaksi kemudian terjadi, hibah fasilitas kendaraan berupa mobil diberikan kepada PCNU. Namun seiring perjalanan waktu, terjadi disharmoni ketika Marjdoko tidak kunjung memenuhi janji politik terhadap warga nahdliyin (Kompas, 2010). Tidak dipungkiri posisi Taifur di pemerintahan pasca kemenangan menjadi penting, juga beberapa kali turut andil dalam menuntut janji politik Mardjoko terhadap warga nahdliyin di pedesaan. Selang beberapa waktu pasca insiden demonstrasi yang dilakukan warga NU, Taifur dicopot sebagai Kepala Pusdiklat dan diturunkan sebagai camat. Sedangkan Ratimin yang ketika itu menjabat sebagai Kepala Kesbangpolinmas sekaligus Wakil Ketua PCNU diturunkan tingkat jabatannya dan ditarik menjadi staf ahli bupati.

Sementara pada Pilkada 2013, Mardjoko dan Husein kembali berlaga. Hanya saja, kali ini mereka menjadi rival. Jika tahun 2008 mereka bersatu dan diusung PKB, tahun 2013 pasangan Mardjoko diusung oleh Partai Golkar dan pasangan Husein diusung oleh PDIP. Singkat cerita laga politik dimenangkan oleh pasangan Husein yang diusung PDIP. Bahkan, baik Mardjoko dan Husein bukanlah kaum nahdliyin. Menariknya, Husein turut menggandeng PPP yang ketika itu diketuai oleh Gus Anam.

Namun, PPP sebagai partai yang menganggap bagian dari representasi NU 
ternyata kurang memiliki pengaruh yang signifikan dalam mencaplok suara. Negosiasi politik pun kembali terjadi. NU kembali memegang kendali melalui pembentukan tim Syiasah, yang berujung kemenangan dan menenmpatkan orang dari kalangan nahdliyin sebagai sekretaris daerah.

Hal ini memperlihatkan bahwa pada Pilkada 2008 dan 2013 di Kabupaten Banyumas, aktor demokrasi, dan partai politik tidak selalu bergandengan tangan dan konsisten bekerja sama dengan pihak lain. Setiap afiliasi selalu diiringi dengan kepentingan antarpihak. Pertarungan kekuatan dan modal terjadi dalam arena ini. NU sebagai aktor intermediari tidak hanya mampu memanfaatkan peluang ini untuk kepentingan politik dan ideologi Islam mereka, lebih dari itu, NU bisa dikatakan sebagai pemain utama, penentu arah kemenangan. Hanya saja NU tidak mencolok tampil ke depan. Perlu diingat, NU bukanlah partai politik namun memiliki basis massa dan ideologi Islam yang kuat dan turut andil mewarnai kontestasi Pilkada di Banyumas.

Kemenangan kepala daerah yang diusung oleh NU bukanlah semata kemenangan sang calon, namunjuga merupakan kemenangan NU. NU mampu mengatur permainan kemudian memenangkannya. Tentu saja dengan syarat bahwa jika menang calon yang diusung harus memiliki komitmen yang kuat kepada NU dan berpihak kepada NU. Kemenangan NU tersebut tidak bisa dilepaskan dari bekerjanya aktor NU, yaitu kyai, di dalam arena.

Para kyai mendayagunakan seluruh kekuatan yang dimiliki. Entah dalam bentuk mendanai kampanye calon yang diusung (modal ekonomi), membangun jejaring dengan pemikir politik untuk memenangkan sang calon (modal sosial), serta memanfaatkan peran dan posisi sebagai kyai, cendekiawan, dan guru untuk memobilisasi atau mempengaruhi nahdliyin sebagai pemilih (modal budaya). Modal simbolis pun dapat dimanfaatkan karena kyai sebagai orang yang dituakan, dianggap mempunyai daya kharismatik untuk menjalankan itu semua demi kemenangan calon yang diusung.

Berdasarkan pemaparandiatas, bekerjanya segala bentuk modal, struktur sosial kehidupan nahdliyin di Banyumas yang dibentuk berpuluh tahun, diwarisi, dan dilestarikan, serta Pilkada sebagai arena pertarungan, telah menjelaskan peran NU. Organisasi tersebut berperan dengan segala konfigurasi dan akumulasi modal yang dimiliki, hingga mampu membelokkan pakem yang sudah ada tentang definisi NU maupun percaturan politik di Banyumas.

Tujuan politik NU terdiri atas tiga bagian utama yang sangat berhubungan dengan tujuan keagamaan. Pertama, menyalurkan dana pemerintah kepada masyarakat NU, terutama untuk meningkatkan fasilitas pendidikan dan keagamaan, seperti pesantren, madrasah, dan masjid; dan juga membangun dan merawat prasarana sosial, seperti klinik kesehatan, panti asuhan, dan balai pertemuan. Kedua, berusaha mendapatkan peluang bisnis dan pemerintah bagi NU dan pendukungnya.

Peluang semacam ini akan memberikan keuntunganlangsungkepadapihakyang mampu mendapat kedudukan dan dianggap dapat membantu Islam dan umat pada umumnya. Semakin sejahtera anggota masyarakatnya semakin meningkat pula kemampuan mereka untuk memenuhi kewajiban sosial dan keagamaannya. Beberapa contohnya seperti menunaikan ibadah haji, membayar zakat, dan mendukung upaya peningkatan pendidikan Islam dan kesejahteraan. Kesejahteraan sangat diperlukan karena sebagian besar sumbangan berupa uang dan materi dari kalangan umat Islam yang kaya (Fealy, 2011: 83).

\section{Kesimpulan}

Kecenderungan NU yang berpihak kepada pemerintah atau status quo adalah pilihan politik yang semata-mata mengedepankan kepentingan umat. Kepentingan umat menjadi tujuan utama untuk berposisi dalam sebuah 
pertarungan. Tak peduli dicap sebagai oportunis, pragmatis, bahkan transaksional, selagi pilihan politik itu menuju kemaslahatan umat dan tidak bertentangan dengan ajaran Islam, bagi NU di Banyumas tidaklah persoalan. Kemaslahatan dan kesejahteraan umat Islam adalah agenda utama bagi NU guna menjalin relasi dengan partai politik. Terlepas NU mendapat banyak cibiran dan cemoohan dari berbagai peneliti, khususnya peneliti dengan perspektif modernis, yang melihat ini sebagai gejala negatif dan 'tak tahu malu' dalam berpolitik, ketaatan kepada kepentingan umat adalah segalanya.

Posisi ini menjelaskan bahwa guna mencermati NU sebagai organisasi keagamaan di Banyumas yang konon katanya adalah organisasi Islam kelas bawah, dibutuhkan beberapa perspektif untuk lebih kritis melihat manuver, pandangan, dan afiliasi politik dari organisasi ini. Seperti yang dijelaskan Greg Fealy (2011: v), kaum atau peneliti modernis menyimpulkan bahwa NU adalah organisasi keagamaan yang oportunis dan 'tak tahu malu' karena tak ada konsistensi dalam mendukung kubu atau kelompok yang bertarung.

NU cenderung merapat kepada kubu pemenang dan enggan menjadi oposisi. Padagal, jika fenomena ini dicermati dari perspektif tradisionalis atau dari dalam NU sendiri, keengganan beroposisi dengan pemerintah merupakan strategi untuk memperoleh peran dan posisi penting dalam pemerintahan Tujuannya adalah terjaganya kepentingan dan kebutuhan kemaslahatan umat yang berjumlah banyak dan menyebar itu.

Terlepas dari pengaruh atau stigma dikotomi baik dan buruknya peran dan relasi NU dengan partai politik dan pemerintah daerah di Banyumas, dua Pilkada ini memperlihatkan bahwa NU berperan besar dalam pemenangan pemilu serta pembuatan kebijakan daerah di Banyumas. Elit NU dan warga akar rumputnya saling menopang kepentingan, dalam proses pemilihan kepala daerah.
Kekalahan Mardjoko pada Pilkada 2013 adalah bentuk resistensi warga NU yang sudah dikecewakan. Sedangkan kemenangan Husein sama sekali tidak berkaitan dengan mitos yang terbangun, bahwa NU setia dengan PKB, atau PKB adalah NU. Mitos itu dipatahkan bahwa apapun partai yang menjadi tunggangan, selagi kepentingan NU turut dibawa, maka NU akan setia menemani dan membantu.

Hal ini agaknya juga berkaitan dengan tren kemenangan PDIP yang menjadikan Jawa Tengah sebagai kantong suara terbesar, serta Sosok Joko Widodo yang tengah naik daun dan PDIP yang kecipratan dari kepopuleran Jokowi. Aspek ini agaknya juga tak bisa diabaikan. Pada titik akhir, Pilkada adalah kontestasi antara NU dengan aktor demokrasi.

Jika merunut kepada khitah NU. Ada dua hal yang perlu dipertimbangkan dengan orientasi NU ketika berelasi dengan politik (Misrawi, 2004). Pertama, pandangan Khitah 1926. Khitah sebagai pandangan meniscayakan adanya wawasan keagamaan yang mampu menerjemahkan visi keulamaan dalam konteks pemberdayaan, pencerdasan, dan penyejahteraan masyarakat.

Kedua, sikap Khitah 1926. Sikap ini merupakan kelanjutan dan penerjemahan praksis dari pandangan khitah. Sikap meniscayakan upaya pemberdayaan dan pembebasan warga NU dari kemiskinan, kemelaratan, dan kelaparan. Para ulama atau kyai melihat pentingnya pengembangan ekonomi, selain pengembangan tradisi keilmuan. Di sini, Nahdlatul Ulama hakikatnya juga berarti nahdlatul tujjar, yaitu kebangkitan para pedagang.

Fungsi keulamaan bukan hanya fungsi keilmuan, tetapi fungsi pemberdayaan ekonomi. Di sini, sikap Khitah 1926 menyimpan makna transformasi sosial. Oleh karena itu, sikap ini dalam konteks NU sekarang harus menghidupkan ekonomi di tingkat mikro dan ekonomi kerakyatan. Pemberdayaan petani, nelayan, dan buruh harus mendapat 
perhatian semestinya karena hakikat NU adalah organisasi kemasyarakatan yang mengemban amanat dapat melakukan kerjakerja pemberdayaan, khususnya ekonomi.

NU sebagai organisasi keagamaan, lembaga intermediari yang berdiri sendiri, sebagai perpanjang tangan antara masyarakat dannegaratidakmelulu dicermati dariperspektif yang mereduksi NU, yaitu memosisikan sebagai sang oportunis dan 'tak tahu malu'. Lebih dari itu, NU mencoba mengembalikan posisinya sebagai organisasi keagamaan yang berorientasi kepada kepentingan dan kemaslahatan umat.

Berubah-ubahnya dukungan politik NU pada dua periode Pilkada di Banyumas menjelaskan bahwa NU berpihak kepada kubu yang kira-kira mampu menjamin kemaslahatan umatnya kelak. Tak peduli dengan stigma inkonsistensi yang dilabelkan kepada NU. Kesejahteraan dan kemaslahatan umat Islam di Banyumas jauh lebih penting dari sekadar dipuja sebagai organisasi konsisten dan sportif dalam kancah politik, jika memilih beroposisi dengan pemerintah. NU tak kenal oposisi, NU hanya konsisten berpegang pada ideologi keagamaan yang mengedepankan kepentingan dan kebutuhan para umat atau pengikutnya.

\section{Daftar Pustaka}

Bourdieu, Pierre. (1979). Symbolic Power",cb dalam D. Gleeson (Ed.); Identity and Structure: Issues in the Sociology of Education. Driffield: Nafferton Books.
(1980). The Production of Belief: Contribution to an Economy of Symbolic Goods. Media, Culture, and Society page 93261. Sage Publications.

. (1983). 'Erving Goffman, Discoverer of the Infinitely Small', dalam Theory, Culture and Society page 13-112. Sage Publications. . (2002). Distinction: A Social Critique of the Judgement of Taste. Terjemahan Richard Nice. Cambridge: Harvard University Press.

Fealy, Greg. (2011). Ijtihad Politik Ulama: Sejarah NU 1952-1967. Terjemahan Farid Wajidi dan Mulni Adelina Bachtar. Yogyakarta: LKiS.

Hasil Keputusan Mukhtamar XXXII Makassar. 22-28 Maret 2010, 6-12 Rabiuts Tsani.

Mahar, Cheleen dan Wilkes, Christopher. (2006). Pierre Bourdieu (1930-2002) dalam Contemporary Critical Theorists: From Lacon to Said. Jon Simons (Ed.). Edinburg: Edinburg University Press.

Makhasin, Lutfi. (2007). Agama dan Budaya Politik: Sufisme dan Habitus Politik Masyarakat Banyumas. Jurnal Swara Politik Vol. 10 No. 1.

Misrawi, Zuhairi. (2004). Reformasi NU. (Online). (http://www.unisosdem.org/ article_fullversion.php?aid $=4680 \&$ coid $=$ $3 \&$ caid $=31 \&$ gid $=2$, diakses 28 Desember 2014).

Pengurus Besar Nahdlatul Ulama. Anggaran Dasar/Anggaran Rumah Tangga Pengurus Cabang Nahdlatul Ulama (AD/ART PCNU) Kabupaten Banyumas tahun 2013. 